Published in Proceedings of Global Marketing Conference 2020, Seoul (online due to COVID-19), 5-8 Novembre 2020, which should be cited to refer to this work.

Global Marketing Conference in Seoul 2020 - full paper submission

\title{
When raindrops turn to the sun shining market intelligence and innovative business models creation in Swiss luxury watchmaking industry
}

\author{
Maria Bashutkina \\ Senior Research Associate \\ Centre du marketing horologer \\ Haute école de gestion Arc \\ RCSO//University of Applied Sciences of Western Switzerland \\ maria.bashutkina@he-arc.ch \\ Espace de l'Europe 21 \\ 2000 Neuchâtel, Switzerland
}

This paper presents the results of qualitative research based on semi-structured interviews with CEO and Marketing managers among Swiss luxury watchmaking companies. We present the highlights on innovative business models and how it could create competitive advantage creation in the highly competitive Swiss luxury watchmaking industry.

Key words:

Marketing strategies, business model, luxury marketing, Swiss watchmaking

\section{Introduction}

According to the Federation of the Swiss Watch Industry (FHS) in 2019, Switzerland occupies only $3 \%$ of the global market regarding the quantity of watches. As for value, Switzerland represents more than $54 \%$ of global sales that is estimated to 21 billion USD. Thus, about $95 \%$ of luxury watches with price starting from 1,000 USD are "Swiss Made" watches.

However, it is not an easy task to get a place in this luxury market of reference. According to the estimation made by the Institute of Watch Marketing, there are approximately 200 active Swiss watch brands on the market today. Under conditions of such a highly competitive market, the challenge concerns not only market share, but also competitive advantage creation.

This context leads us to formulate the following research question: how market intelligence could create additional competitive advantage in Swiss luxury watchmaking industry.

The first section of this article highlights background and methodology of current research paper. The second section presents conceptual framework concerning innovation in marketing models, resourcebased theory and alternative competitive advantage creation. The third section presents the results of the qualitative study and discuss them. The final section presents further researches avenues.

\section{Methodology}

In this article, we apply a two-step approach that brings together literature review and exploratory qualitative research. First, we proceed to the analysis of scientific publications concerning competitive advantage, resource-based theory and market intelligence. Therefore, we proceed to qualitative research (semi-structured interviews with twenty CEO and Marketing managers) among Swiss luxury watchmaking companies as the second part of this research.

\section{Conceptual framework}


Last decades have seen a dramatic economic shift from manufacturing to information and knowledgedriven services. The source of competitive advantage has shifted from product to market intelligence and market based knowledge management (Ramaswami et al., 2009).

In the last twenty years the resource-based theory of the firm received a lot of attention as an alternative to the traditional competitive advantage (product based) proposed by Porter (1980). The resource-based view suggests that the knowledge (as an intangible resource) that the company possess provides greatest ability to create a differentiation and then to get a competitive advantage in a highly competitive market Hunt \& Morgan, 1997).

Over the past years, researchers have increased conceptual understanding of the role of marketing in enabling firms to create and sustain competitive advantage and superior performance. In accordance with potential to improve business performance, some studies have introduced the term 'Dynamic Marketing Capabilities' (Bruni et Verona, 2009; Fang \& Zou, 2009)

Dynamic marketing capabilities (commonly known as the market intelligence) focuse on releasing and integrating market knowledge that helps firms evolve. Under dynamic marketing capabilities, we include what other researchers previously have labelled market sensing and customer-linking capabilities (Ramaswami et al, 2009), customer-oriented capabilities (Vorhie \& Morgan, 2005) and second-order customer competences (Teece \& Pisano, 1997). In this article, we will pay special attention to the insights coming from market intelligence management and their application to creation of innovative marketing models by Swiss watchmaking companies.

Thus, the role of dynamic marketing is ultimately to sustain company's performance by enhancing, combining, protecting and (if necessary) reconfiguring various processes within the company (Bruni \& Verona, 2009). Fang and Zou (2009) define dynamic marketing capabilities as the responsiveness and efficiency of cross-functional business processes. More precisely, we could define it as a complimentary source of information coming from the market, which affects many changes within the company. Dynamic marketing capabilities could help to create innovative business models and help to gain additional competitive advantage.

In our study we will take an inspiration for innovative business models from the findings publishied by M. Merk (2014). She proposes two types of business models. As opposed to traditional "raindrop model" (where we traditionally see very inflexible hierarchy of processes) more innovative business model represent completely opposite view as a "sunshine model" (where flexibility and interconnection of people and processes take a very important part in all business processes within the company).

\section{Main findings}

Analysis of semi-structured interviews with twenty CEO and marketing managers of the Swiss luxury watchmaking companies lead us to a number of findings concerning innovative business models.

The main finding of our explorative qualitative study is the observation that high-end watchmaking companies are founded focusing on specific kind of watches and technological expertise in it. Often, this type of companies tend to develop and grow by mastering their technological competences and even if the market is changing they don't adapt their business models.

Numerous companies participated in the research attested that organized and structured information, absorbed by the company through market intelligence, has a very high importance for the company. However, despite of this importance, rare are companies that applies dynamic business models. Those who have it, use these capabilities mostly for new product creation and very rare for reconfiguration of their processes. Even if the majority of companies confirmed the importance of dynamic structure of the company and innovative marketing strategies, it is very difficult to implement them on practice due to the complexity of the numerous stages of industrial production, various operations and partners. 
Dynamic marketing capabilities application to innovative business model creation were indicated very rarely by companies. Very few companies use market intelligence to adjust their business models, create additional value proposition and valuable customer's relations. We find those examples only on the niche market of very-high-end sophisticated and personalized or even co-created watches. In order to get more inputs, these luxury watchmaking companies propose (online or offline) configuration and personalization of watches according to the wish of the customer.

"For very special demands we propose exclusive service of watch configurator that goes further than just a personalized design of the watch. The heart (the movement of the watch) is personalized and it shapes all structure of the watch after all. Thus, we are talking about absolutely new way of dealing with clients by putting them into the center of our attention. Moreover, all the insides coming from customers are analyzed with much attention and than used for new product development "

Largely applied in other industries this dynamic approach is considered innovative in Swiss luxury watchmaking.

"Due to the volume of production and distribution configuration, most of the well-known brands could not maintain direct contact with all clients and be flexible. While some smaller companies, like us, could create privileged relationships. For example, by additionally initiating various leisure activities for customers we create even stronger emotional attachments with the brand and get to know better our customers and their expectations. To be close to customers also helps us to modify some of our processes, for example in new product creation and distribution.

Traditionally, luxury industries (Swiss high-end watchmaking is not an exception) treat their customers as the last (sometimes even the least) element in the value chain and the "last drop" that comes from the "sky". In order to stand out from competitors and to create additional competitive advantage, market intelligence and "sunshine model" is crucial in the longue run. In this configuration, all processes within the company depend on relevant information coming from the market and its management.
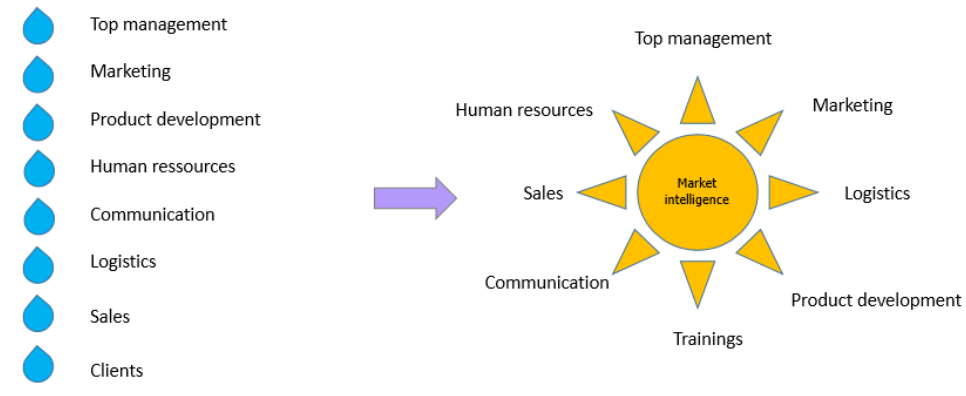

Source: Adapted from M. Merk 2014

\section{Managerial and scientific contributions}

Traditionally, the resource-based theory of competitive advantage was predominantly constructed on the theoretical level. In our opinion, such approach considered as the key drawback of scientific discourse. Recognition that science and practice produce distinct forms of knowledge has been longstanding. According to Van de Ven (2007), the gap between theory and practice may be a knowledge production problem. The aim of the current research is to suggest a vice versa point of view and to highlight empirical evidences coming from practice. It provides and allows analysis and structuring of empirical data gathered in the Swiss watch-making industry.

This research contributes to the development of RBT with insights coming from practice. The novelty of this project lies in its empirical approach applied in order to develop RBT application to the Swiss watchmaking industry. 
Managerial contribution of this article lies in innovative business model proposition that could be used as a support for strategic decision-making by Swiss high-end watch-making companies.

\section{Research limitations and avenues for further research}

The main limitation of this research lies in its nature. The exploratory research helped us to identify the most common marketing processes. However, this does not allow us to understand the depth of this phenomenon. To do this, it would be appropriate to analyses more deeply the case studies of various companies who applies an alternative "sunshine" business model in order to understand best practices and the main elements of this type of business models.

\section{Bibliography}

- Danneels, E. (2011), Trying to become a different type of company: dynamic capability of Smith Corona. Strategic Management Journal, Vol 32, pp. 1-31.

- Day G. (1994), The capabilities of market-driven organi- zations. Journal of Marketing,, Vol 58, pp. 37-52.

- Eisenhardt, K. M., \& Martin, J. A. (2000), Dynamic capa- bilities: What are they? Strategic Management Journal, 21, 1105-1121.

- Fang E. and Zou S. (2009), Antecedentss and consequences of marketing dynamic capabilities in international joint ventures, Journal of International Business Studies, Vol 40, pp. 742-761.

- Helfat, C. E., S. Finkelstein, W. Mitchell, M. Peteraf, H. Singh, D. Teece, S. Winter with C. Maritan (2007), Dynamic capabilities and organizational processes, in Dynamic Capabilities: Understanding Strategic Change in Organizations, pp. 30-45 Blackwell, London.

- Hou J. and Chen Y. (2010), The effect of market knowledge management competence on business performance: a dynamic capabilities perspective. International Journal of Electronic Business Management, Vol 8, pp. 96-109.

- Kozlenkova I., Samaha S. and Palmatier R. (2013), Resource-Based Theory in Marketing, Journal of the Academy of Marketing Science, 41, January, pp.1-21.

- Merk M. (2014) Luxury sales force management: Pilgrave Macmillan

- Porter M. (1980), Competitive Strategy. New York: The Free Press.

- Ramaswami S., Srivastava R., Bhargava M. (2009) Market based capabilities and financial performance of firms: insights into marketing's contribution to firmvalue, Jour- nal of the academic marketing science, Vol 37 pp. 97-116

- Slater, S. F. and J. Narver (1998), Customer-led and market oriented: let's not confuse the two, Strategic Management Journal, 19, pp. 1001-1006

- Srivastava R., Faheyb L. and Christensen H. (2001), The resource-based view and marketing: The role of market- based assets in gaining competitive advantage, Journal of Management, Vol 27, pp. 777-802.

- Teece, D., Pisano, G., and Shuen, A. (1997). Dynamic capa- bilities and strategic management. Strategic Management Journal, 18(7), 509-535.

- Vorhies D. and Morgan N. (2005) Benchmarking marketing capabilities for sustained competitive advantage. Journal of Marketing, 69(1), 80-94.

- Winter, S. (2003), Understanding dynamic capabilities, Strategic Management Journal, 24, pp. 991-995.

- Zahra, S., H. Sapienza, and P. Davidsson (2006), Entrepre- neurship and dynamic capabilities: a review, model and research agenda, Journal of Management Studies, 43, pp. 917-955.

- Zollo, M. and S. Winter (2002), Deliberate learning and the evolution of dynamic capabilities, Organization Science, 13, pp. 339-351. 